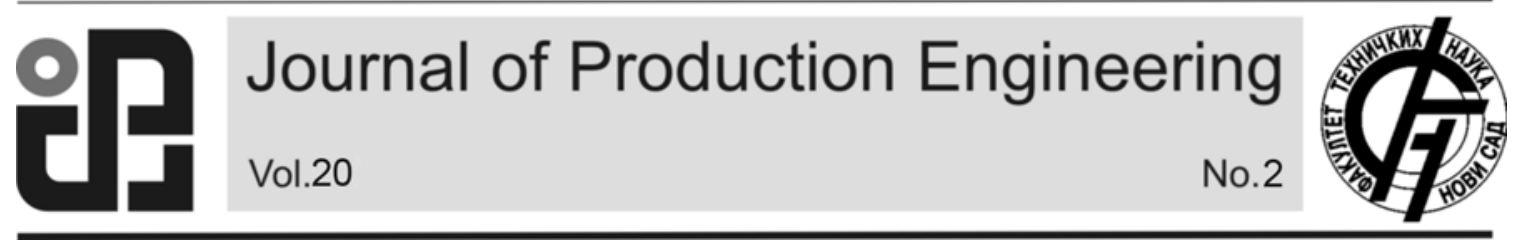

JPE (2017) Vol.20 (2)

Tarić, M., Kovač, P., Nedić, B., Rodić, D., Ješić, D.

Original Scientific Paper

\title{
TOOL WEAR, CUTTING TEMPERATURE AND CUTTING FORCE DURING TURNING HARD STEEL
}

Received: 01 September 2017 / Accepted: 30 November 2017

Abstract: In this study, cutting tool's wear, temperature and forces during turning process were investigated. Used were two types of inserts HM and CBN were taken as cutting tools and round bar of EN 90MnCrV8 hardened steel was used as the workpiece. Since the life of the cutting tool material strongly depends upon cutting temperature, it is important to predict wear and heat generation in the tool. Determination of temperature field in tool was by thermal camera. Determined was dependence of temperature tool wear parameter for two cutting tool materials as well.

Key words: tool wear, cutting temperature, cutting force turning, hard steel.

Habanje alata, temperature rezanja i sile rezanja za vreme obrade struganjem tvrdog čelika. $U$ radu je istraživano habanje alata temperature i sile za vreme struganja. Korišćene su dve vrste pločica za struganje i to tvrdi metal i kubni bor nitrid, a šipka od ojačanog čelika EN 90MnCrV8 kao obradak. Pošto postojanost alatnog materijala jako zavisi od temperature rezanja važno je odrediti temperaturu na alatu. Određivanje temperature je vršeno pomoću termalne kamere. Određena je zavisnost temperature od habanja alata za oba dva ispitivana alatna materijala.

Ključne reči: habanje alata, temperature rezanja, sile rezanja tvrdi čelik.

\section{INTRODUCTION}

In the hard machining process, tool wear and cutting temperature is often of great concern due to its impact on the product performance. Tool wear cutting force and cutting temperature in the metal cutting process is a very important factor affecting production optimization [1]. Therefore, for a desired part performance, it is important to predict and control the development of this parameters and tool material of the hard machining parameters. The importance of temperature prediction for the machining processes has been well recognized in the machining research community, firstly, due to its effects on tool wear and its constraints on the productivity, and secondly, due to a significant impact it has on the integrity of workpiece surface such as residual stress, hardness, and surface roughness [2].

An important advantage in meeting this new challenge is being able to quickly acquire information on specific machining operations [3, 4]. Cutting temperature is the commonest index for determining tool wear [5]. Ay and Yang [6] monitored time wise change in the temperature of the work piece by using infrared thermo-vision to determine the effect of heat transfer on the tool. They concluded that if the tool's temperature is increased that leads to the acceleration of the wearing process. The high cost of specific cutting tools materials and the cost of downtime for tool changing must be minimized [7]. Tool wear plays a key role in the economy of machining operations. Jawahir et al. [8] maintain that knowing the optimum machining parameters is vital.

Hard turning has been receiving increased attention because it offers many possible benefits over grinding in machining hardened steel [9]. The cubic boron nitride inserts are commonly used in hard turning, because of the high cost of $\mathrm{CBN}$ inserts. It is minimized cutting temperature which directly influences the tool wear. In turning process, cutting temperature depends on the options and the suitability of different cutting speeds, feeds, cutting depth and it also affects the durability of the cutting tool [10]. Due to these aspects, measuring procedures are necessary as they permit one to establish the real state of tool wear and to manufacture parts with higher accuracy [11]. The thermo-graphic technique has commonly been used to measure the temperature of the cutting tool. Muller et a1. [12] measured the temperature distribution on the rake face of the diamond coated tool in turning using a thermo-graphic technique. This technique is used for researching the correlations between cutting parameters and temperature distribution in the zone of cutting [13].

Hardened steel is usually machined by grinding process and here is used the turning process which is a more effective machining process with a satisfied quality. Cutting temperature is an important issue in the machining processes and it is influenced by the process parameters such as tool geometry (i.e. nose radius, edge geometry, rake angle, tool tip radius, chamfer thickness, etc.), cutting conditions (cutting speed, feed, depth of cut, etc.) and workpiece properties. Contribution of this paper is seen in the fact that not only modeling is done by neural network, but the comparison of two CBN (cubic boron nitride) inserts with different tool geometry, a negative rake angle and zero angle, is shown. Comparative observation showed that zero angle gives slightly smaller deviation in the cutting temperature values for $\mathrm{CBN}$ than HM. 
Cutting conditions during study were $\mathrm{a}=0.22 \mathrm{~mm}$, $\mathrm{s}=0.1 \mathrm{~mm} / \mathrm{o}, \mathrm{v}=90 \mathrm{~m} / \mathrm{min}$.

\section{EXPERIMENTAL SETUP}

The main aim of the experiments was to determine tool wear, cutting temperature and cutting force in the turning of cold working hardened steel for different tool materials. This steel was heat treated and hardness of $55 \mathrm{HRC}$ was obtained in the machining zone of every workpiece. Machining was performed without cooling and lubrication agents.

Turning operations were realized with constant values of cutting speeds (v), feed (f), and the depth of cut (a) using cubic boron nitride (CBN) and hard metal (HM) tool inserts, table 1.

\begin{tabular}{|c|c|c|c|c|c|c|}
\hline Inserts & $\gamma\left[^{\circ}\right]$ & $\alpha\left[^{\circ}\right]$ & $\lambda\left[^{\circ}\right]$ & $\kappa\left[^{\circ}\right]$ & $\kappa 1\left[^{\circ}\right]$ & $\mathrm{r}[\mathrm{mm}]$ \\
\hline CNMA120404 & -6 & 6 & -6 & 91 & 5 & 0.4 \\
\hline
\end{tabular}

Table 1. Specifications of tool insert

The workpiece material was $\mathrm{EN} 90 \mathrm{MnCrV} 8$ cold working tool steel with the following chemical composition: $0.90 \% \mathrm{C}, 0.20 \% \mathrm{Si}, 2.00 \% \mathrm{Mn}, 0.40 \% \mathrm{Cr}$, and $0.10 \% \mathrm{~V}$. Turning test was performed in longitudinal turning on the round bar with $34 \mathrm{~mm}$ diameters and $500 \mathrm{~mm}$ length using conventional lathe with $10 \mathrm{~kW}$ spindle power. During the turning test, and negative tool rake angle, cutting temperatures were recorded. A FLIR E50 thermal imaging camera was used to measure the cutting temperatures. Thermal camera was positioned and fixed on a tool holder. The camera moved with the tool and monitored the same area on it. The emission factor of 0.95 for steel was adopted as the highest temperature on the chip was measured. The thermal camera measured maximal temperature, minimal temperature and average temperature in the selected area. The temperature in the pointed spot on the tool was also measured and this temperature was used in calculations by ANN modeling. The temperature was monitored during the machining of one whole section on the workpiece and the value obtained after 5 seconds was used for the calculation.

Two types of inserts were used in these tests CBN and TM: CNMA120404 and CCMW120404 (table 1 and table 2). Through the use of tool holders, a negative rake angle $y=-6^{\circ}$ was obtained for the tool holder PCLNR2525M12.

\subsection{The cutting force measurement}

The acquisition system for measuring the cutting force applied for experimental research in this paper is characterized by the following components:

- Turning process (machine tool, cutting tool, worpiece),

- Measuring sensor (three-component dynamometer KISTLER Type 92651A1),

- Device for amplification of measuring signal (amplifier KISTLER type Ca5001),
- Acquisition module (AD converter converters) Burb Brown type 2000 and PC / AT $48633 \mathrm{MHz}$

- PC / AT $48633 \mathrm{MHz}$ PC for software acquisition, software LT / CONTROL Ver. 5.02.

In order to monitor the process of machining and recording the signal to the computer disk, a user application was created that enabled the continuous graphical display of the signal components of the cutting force, its current numerical value, and the calculation of the mean value of the signal within the given limits.

In order to determine the character and size of wear process versus time, the width of the tool flank wear land on the back surface was performed after each passage of the $82 \mathrm{~mm}$ tool length, which lasted 70 seconds (1.16 $\mathrm{min})$. The wear measurement was performed on the Zeiss tool microscope and images of wear progression was made as well.

The machine tool was a universal lathe Prvomajska DK480. The universal was installed in the Metal Processing by cutting Laboratory at the Faculty of Mechanical Engineering in Kragujevac. The machine tool (universal lathe - Prvomajska DK480) has the following characteristics: power of the electric motor $10 \mathrm{KW}$, the maximum machining diameter is 320 $\mathrm{mm}$, the maximum machining length is $2000 \mathrm{~mm}$.

\section{RESULTS AND DISCUSSIONS}

In accordance with the description in the previous section, the measurement of the width of flank wear land the VB versus cutting time for the HM tool insert material in the Figure 1 is presented, and for the CBN is presented in the Figure 3. Images of wear versus time for $\mathrm{HM}$ and shown in Figure 2 and in Figure 4 for CBN.

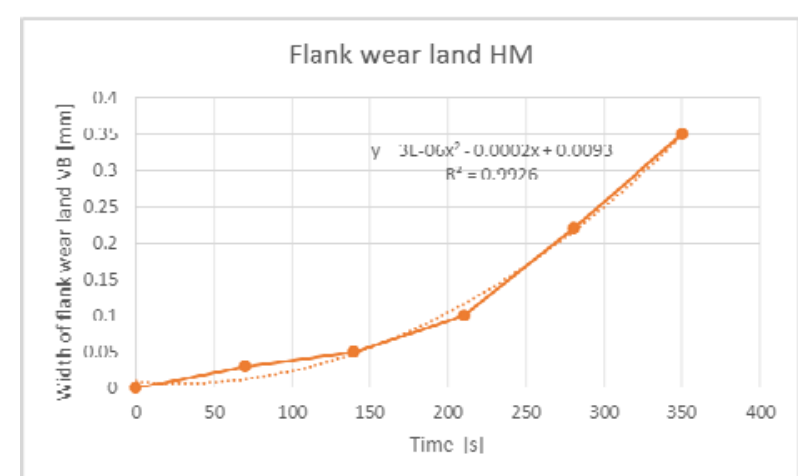

Fig. 1. Flank wear land HM

The cutting temperature versus time measured by the thermal camera is shown in Fig 5 for HM and Fig 6 for $\mathrm{CBN}$.

The progresion of the cutting force versus time is more significant for HM Fig 7, than for CBN Fig 8, where values are significantly lower. Higher values are for cutting force component F2 than F1.

Dependence of the cutting temperature value in the function of tool wear for both tested materials is shown in the Fig 9 and Fig 10. The figures also show the dependencies that are valid for the high values of the coefficient of correlation. 


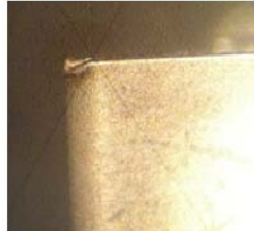

$210 \mathrm{sec}$

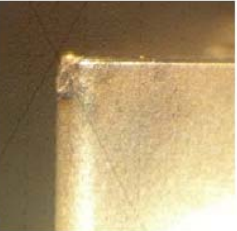

$280 \mathrm{sec}$

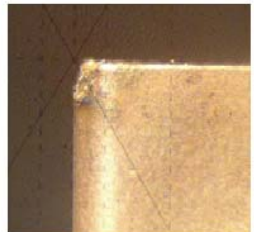

$350 \mathrm{sec}$
Fig. 2. Progresion of hard metal insert wear images

The width of flank wear land versus time can be represented by a second-order polynomial function with the higher value of correlation coefficient for both tool materials. On the basis of the analysis of the time progression of the tool wear, it can be concluded that the hard metal insert wear process is much faster than the CNB insert at a constant cutting conditions. The CBN insert was only slightly wear and the TM plates were completely wear $(\mathrm{VB}=0.35 \mathrm{~mm}$ ) after 350 seconds.

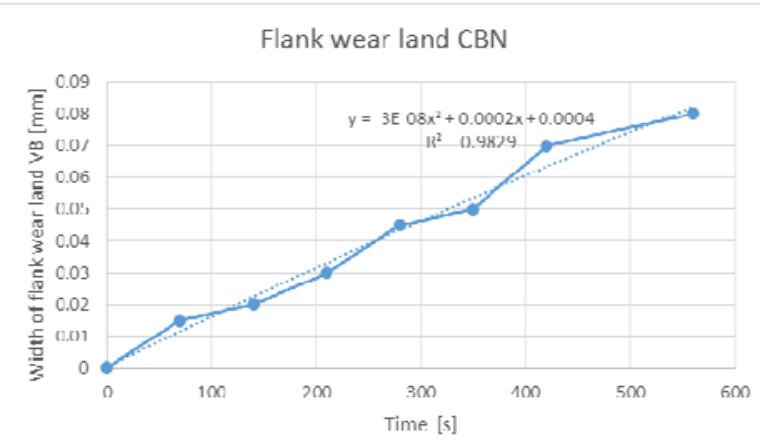

Fig. 3. Flank wear land CBN

The cutting-temperature time progression can also be represented by a second-order polynomial function. The cutting temperature for both tested tool materials has a similar value, but $\mathrm{CBN}$ is somewhat lower $\left(330^{\circ}\right.$ C) than $\mathrm{HM}$ (for $\mathrm{HM} 360^{\circ} \mathrm{C}$ ). The timing of the temperature change is similar to the change in wear and therefore there is a good correlation with the wear of the images.

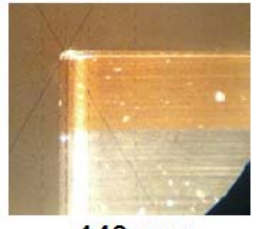

$140 \mathrm{sec}$

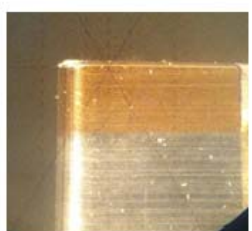

$350 \mathrm{sec}$

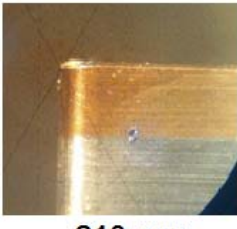

$210 \mathrm{sec}$

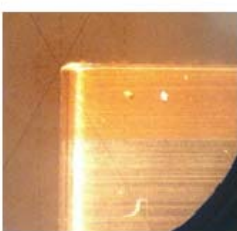

$420 \mathrm{sec}$

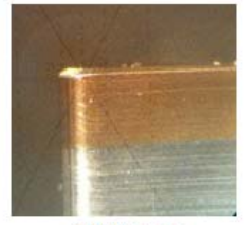

$280 \mathrm{sec}$

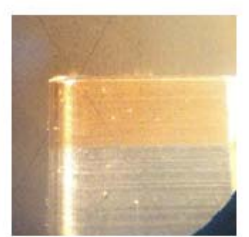

$560 \mathrm{sec}$
Fig. 4. Progression of $\mathrm{CBN}$ insert wear images

Progression of the cutting temperature value in the tool wear function for both examined materials shown in the Fig 9 and Fig 10, can be represented by linear regression and second-order polynomial and are valid with high values of correlation coefficients.

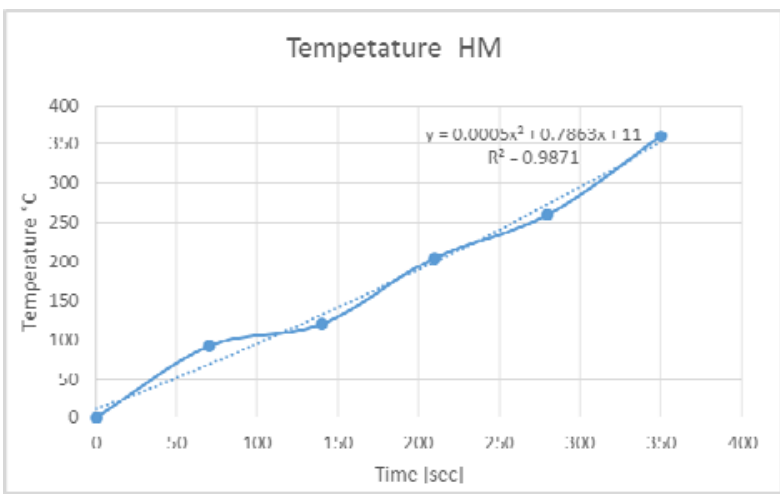

Fig. 5. Temperature versus time

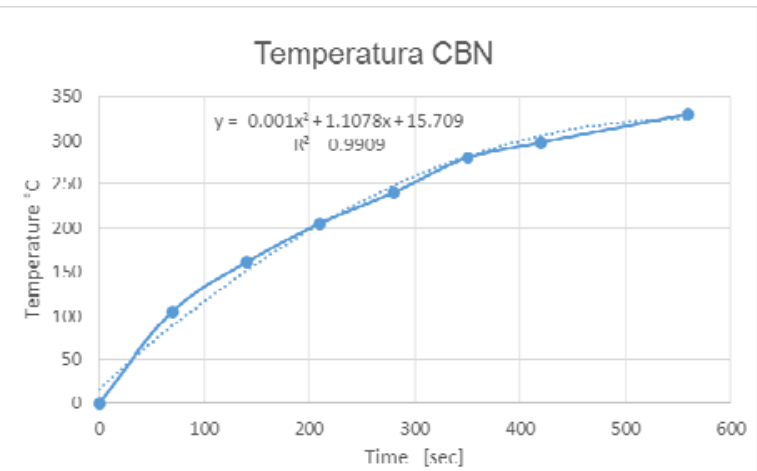

Fig. 6. Temperature versus time

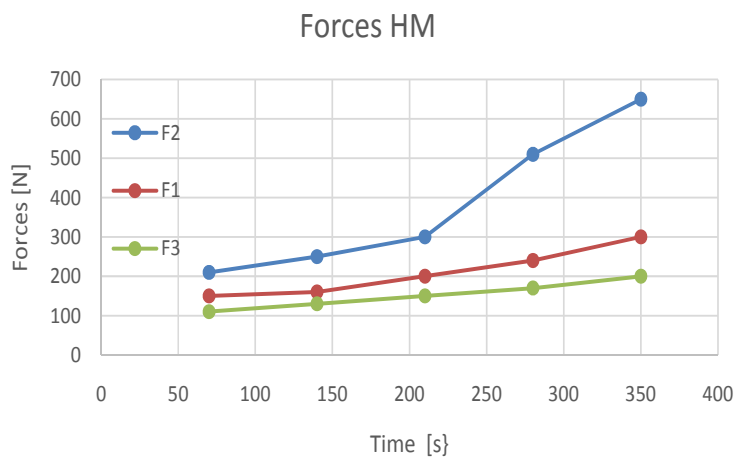

Fig. 7. Cutting force versus time

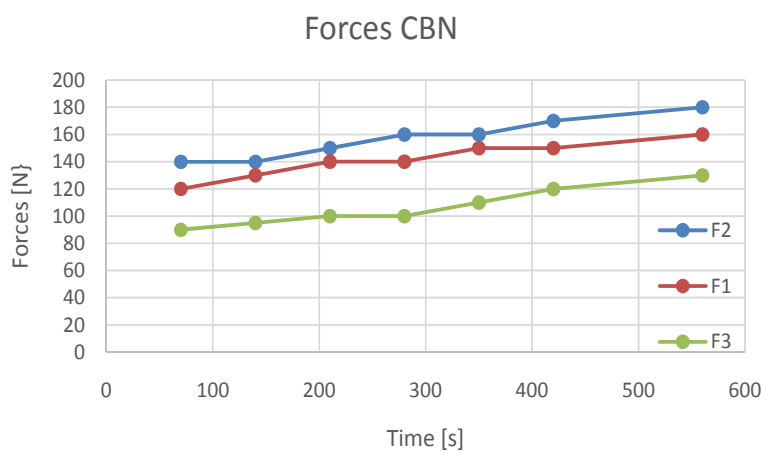

Fig. 8. Cutting force versus time

The higher values of the coefficient of correlation are find for the second-order polynomial model. The change of the cutting force in time is more significant for $\mathrm{HM}$ than $\mathrm{CBN}$, where values are significantly lower. Higher values are for cutting force component F2 than F1. As wear progression go on For HM there is an abrupt jump of the cutting force components in time. 


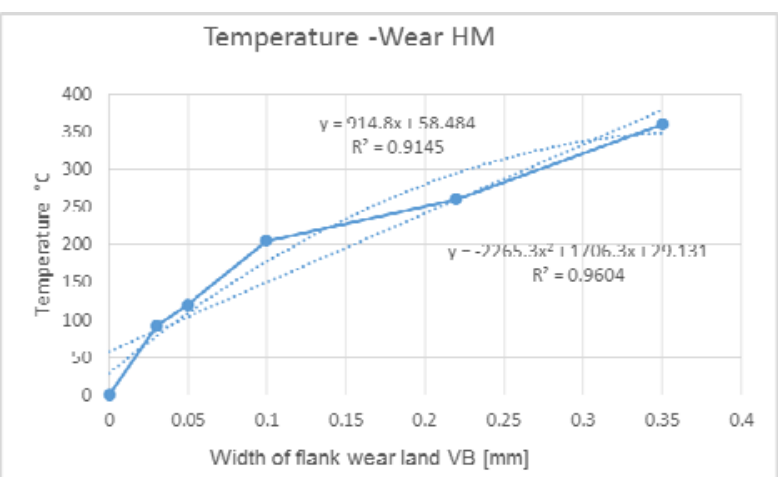

Fig. 9. Temperature versus wear

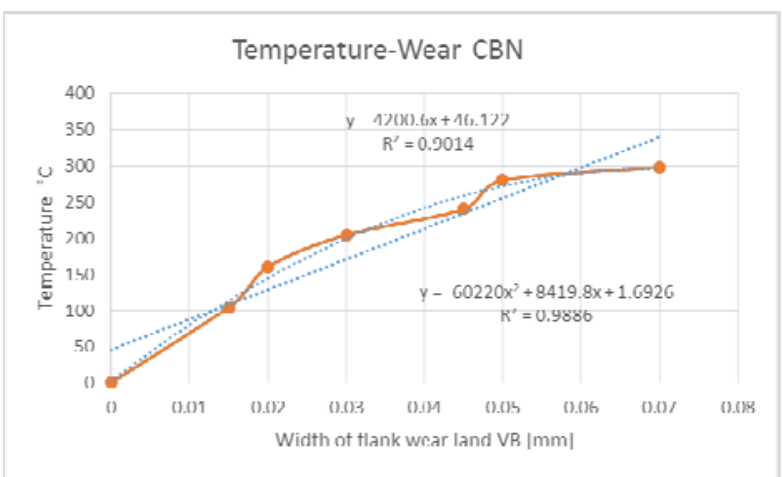

Fig. 10. Temperature versus wear

\section{CONCLUSION}

Equations On the basis of the analysis of the time progression of the tool wear, it can be concluded that the hard metal insert wear process is much faster than the CNB insert at a constant cutting conditions. The CBN insert was only slightly wear and the HM plates were completely wear $(\mathrm{VB}=0.35 \mathrm{~mm}$ ) after 350 seconds.

The change of the cutting force versus time is more significant for HM Fig 7, than for CBN Fig 8, where values are significantly lower. Higher values are for cutting force component F2 than F1.

Progression of the cutting temperature value in the tool wear function for both examined materials can be represented by linear regression and second-order polynomial and are valid with high values of correlation coefficients. The higher values of the coefficient of correlation are find for the second-order polynomial model.

\section{REFERENCES}

[1] Sharma, V.S., S.K. Sharma, and A.K. Sharma, Cutting tool wear estimation for turning. Journal of Intelligent Manufacturing, 2007. 19(1): p. 99108.

[2] Kovac, P., et al., Application of fuzzy logic and regression analysis for modeling surface roughness in face milliing. Journal of Intelligent Manufacturing, 2012. 24(4): p. 755-762.

[3] Pontes, F.J., et al., Artificial neural networks for machining processes surface roughness modeling. The International Journal of Advanced Manufacturing Technology, 2009. 49(9-12): p.
879-902.

[4] Kovac, P., et al., Multi-output fuzzy inference system for modeling cutting temperature and tool life in face milling. Journal of Mechanical Science and Technology, 2014. 28(10): p. 4247-4256.

[5] Andjelkovic, B., et al., Modeling steady-state thermal defectoscopy of steel solids using two side testing. Thermal Science, 2016. 20 (suppl. 5): p. 1333-1343.

[6] Ay, H. and W.J. Yang, Heat transfer and life of metal cutting tools in turning. International Journal of Heat and Mass Transfer, 1998. 41(3): p. 613-623.

[7] Nedic, B. and M. Eric, Cutting temperature measurement and material machinability. Thermal Science, 2014. 18(suppl.1): p. 259-268.

[8] Jawahir, I.S., et al., Towards integration of hybrid models for optimized machining performance in intelligent manufacturing systems. Journal of Materials Processing Technology, 2003. 139(1-3): p. 488-498.

[9] Huang, Y. and T.G. Dawson, Tool crater wear depth modeling in CBN hard turning. Wear, 2005. 258(9): p. 1455-1461.

[10] Ueda, T., et al., Temperature on Flank Face of Cutting Tool in High Speed Milling. CIRP Annals - Manufacturing Technology, 2001. 50(1): p. 3740.

[11] Ueda, T., et al., Temperature Measurement of CBN Tool in Turning of High Hardness Steel. CIRP Annals - Manufacturing Technology, 1999. 48(1): p. 63-66.

[12] Müller-Hummel, P. and M. Lahres, Infrared temperature measurement on diamond-coated tools during machining. Diamond and Related Materials, 1994. 3(4-6): p. 765-796.

[13] Tarić M., Kovač, P., Nedić, B., Rodić, D., Ješić, D. Monitoring and neural network modeling of cutting temperature during turning hard steel. Thermal Science, online first, doi: https://doi.org/10.2298/TSCI170606210T.

Authors: ${ }^{1}$ Mirfad Tarić, ${ }^{2}$ Prof. Pavel Kovač PhD, ${ }^{3}$ Prof. Bogdan Nedić PhD, ${ }^{2}$ Dragan Rodić MSc, ${ }^{4}$ Dušan Ješić PhD. ${ }^{1}$ Faculty of Mechanical Engineering, University of East Sarajevo, East Sarajevo, Bosnia and Herzegovina. ${ }^{2}$ University of Novi Sad, Faculty of Technical Sciences, Department for Production Engineering, Trg Dositeja Obradovica 6, 21000 Novi Sad, Serbia. ${ }^{3}$ Faculty of Engineering, University of Kragujevac, Kragujevac, Serbia. ${ }^{4}$ MTM Academia, Novi Sad, Serbia.

E-mail: mirfad.taric@hotmail.com pkovac@uns.ac.rs nedic@kg.ac.rs rodicdr@uns.ac.rs dusanjesic@hotmail.com 